\title{
Evaluation of solid waste management at campus using the "Zero Waste Index": The case on campus of Islamic University of Indonesia
}

\author{
Kasam*, Fajri Mulya Iresha, and Satrio Ajie Prasojo \\ Department of Environmental Engineering, Faculty of Civil Engineering and Planning, Islamic University of Indonesia, Yogyakarta \\ Indonesia, 55584
}

\begin{abstract}
Faculty of Civil Engineering and Planning (FCEP) Islamic University of Indonesia (UII) after doing zero waste program which has been going on September 2016. Zero waste concept are needed to measure how far the ability virgin material substitution to balance with the system of zero waste. The aims of this research is to calculate zero waste index (ZWI) value, to know the impact of zero waste index, and to give the solution for zero waste program. The location was doing in FCEP UII Campus. The method of sampling was using for this research is refers to SNI 19-3964-1994 about to calculate waste generation of residential. The result shows value of zero waste index at FCEP UII are 0,26. FCEP UII reuse 134,19 $\mathrm{kg}$ waste of total $516,37 \mathrm{~kg}$ waste that has been produced. The waste that has been reuse is organic waste $87,93 \mathrm{~kg}$, plastic waste $21,49 \mathrm{~kg}$, and paper waste $24,77 \mathrm{~kg}$. $80,10 \%$ FCEP peoples already know about zero waste program at FCEP UII. 98,90\% of FCEP peoples, was agree with waste segregate, and 57,50\% FCEP peoples are don't know that waste from FCEP have been manage. Although as many as $29 \%$ of element campus do not understand about the zero waste program but the majority of them support the program.
\end{abstract}

Keywords : Zero Waste, Zero Waste Index, Waste Generation

\section{Introduction}

Rapid urbanization, population growth, migration to urban areas, lack of sufficient funds and affordable services often force city authorities to offer unreliable and inefficient waste management services [1]. Increasingly people move from rural to urban environments due to the economic activities and quality of life provided to inhabitants, causing cities to expand. Over-crowded cities are compromising the quality of urban life due to their rapid growth and ever-increasing generation of waste. One of the important mandates in the Law No. 18/2008 in the implementation of waste separation, reduction, reuse and recycle. Waste management carried out by the community has been started and is developing in many cities. Activities related to community involvement consist of separation, composting (at source and communal), and recycling. The municipality is the responsibility for the transportation of the residue to disposal sites [2]. Worldwide, the higher education (HE) sector has expanded phenomenally; for example, since the 1960s, the United Kingdom (UK) HE system has expanded sixfold to $>2.4$ million students. As a consequence, the overall production of waste at HEIs throughout the world is very large and presents significant challenges as the associated legislative, economic and environmental pressures can be difficult to control and manage [3].
In traditional waste management systems, waste is considered an 'end-of-life' product, produced in the last phase of the product-consumption process. Zero waste challenges the traditional definition of waste by recognising that waste is a transformation of resources which happens in the intermediate phase of the resource consumption process. The resources that are transformed into waste as a result of our consumption activities should therefore be redirected into the production process through holistic zero waste management systems. Thus zero waste management is a combination of integrated design and waste management philosophies. The zero waste index is a tool to measure the potentiality of virgin materials to be offset by zero waste management systems. One of the important goals of the zero waste concept is zero depletion of natural resources. Therefore, measuring the performance of the zerowaste city would eventually measure the resources that are extracted, consumed, wasted, recycled, recovered and finally substituted for virgin materials and offset resource extraction by the waste management systems [4].

Within the zero waste philosophy, product design and waste management principles are considered simultaneously to eliminate potential threats to the environment caused by human consumption and unsustainable behaviour. Zero waste product design ensures that the discarded product is easily reused and/or repaired to extend the product's lifespan. A zero waste

\footnotetext{
Corresponding author: kasam@uii.ac.id
} 
product is created by applying cradle-to-cradle design principles which eliminate waste from a product's life cycle. A zero waste product eliminates the 'waste phase' from the traditional product life cycle because after the end-of-life phase the zero waste product can either be reused, repaired or remanufactured to produce a secondary product. Zero waste management processes ensure that the discarded waste be recycled, recovered or easily nourished through natural processes, without polluting our natural environment. Hence the concept of zero waste safeguards the optimum utilization of natural resources with minimal environmental degradation [5]. The past decade has seen many researchers motivated to develop new approaches to waste management systems based on zero waste concepts. The major work in zero waste research has been done by [6] shown that the campus of University of Tabriz produced 2.5 metric tons of wastes per day that more than $80 \%$ of it could be diverted through waste reduction, recycling and composting activities. Compostable organic material was the most significant waste type.

The major work in zero waste research has been done by $[7-10]$. This research has identified the most vital areas of zero waste studies as consumption of resources, individuals' consumption behaviour, and product design based on cradle-to-cradle principles (ecoeffective product and system design), maximum waste diversion from landfill and optimum resource recovery. Waste diversion rates (determined by calculating the amount of waste diverted from landfill) are one of the performance assessment indicators for waste management systems [11]. As a performance indicator, waste diversion has different socio-economic and environmental issues [12] and has received criticism [4] from researchers due to its limited forecasting capacity. [13] proposed the ZWI as an alternative performance assessment tool. The higher ZWI value represents higher substitution of virgin materials, energy and water saving i.e. higher achievement. The study compared the waste management performance of Adelaide, San Francisco and Stockholm based on the virgin material substitution factor, energy, GHG and water savings from their respective waste management systems. The study found that San Francisco's municipal solidwaste management system has the highest virgin material substitution potentiality and that, in 2010, its Zero Waste Index was 0,51 with a $72 \%$ diversion rate followed by Adelaide $(Z W I=0,23)$ and Stockholm $(Z W I$ $=0,17$ ).

The aim of this study is determine the performance of waste management systems on campus by calculating the amount of solid waste diverted from landfill are one of assessment indicators.

\section{Material and Methods}

This study was conducted during the 2015-2016 academic year on the main campus of the FCEP UII. The faculty had, approximately, 6500 students and 150 staff work in the year of study. The research consisted of five main stages as below:

- Estimation of amount of daily generated solid wastes
- Waste characterization, analysis of the amounts and types of wastes.

- Determining the ZWI based on strategy for solid waste management within faculty

\subsection{Estimation of Solid Waste Generation}

In order to determine the solid wastes generation has been carried out sampling for 8 days in FCEP UII campus. Prior to sampling, waste disposal spots were identified and campus was divided into nine subareas according to the type of activity. These subareas included academic departments of the university (faculties, labs and workshops), administration buildings, health center, sport center, dormitories, staff residential area, conference halls, canteen and cafeterias and university gardens. Sampling methods and procedures for characterization of the wastes were derived through using Standard Test Method for Determination of the Composition of Unprocessed Municipal Solid Waste (SNI 19-39641994). Furthermore the reviews of studies performed by different universities and countries were used. According to ASTM recommendations, samples weighed 200 to 300 pound ( 91 to $136 \mathrm{~kg}$ ) can be chosen and a single sample of $100 \mathrm{~kg}$ is a good representative of the total waste characteristics (ASTM, 2001). All samples were taken during on working days to ensure that the sampling results represent the normal university operations during the academic year. A total of nine sampling loads, one for each subarea, were scheduled over one week during each month of year. Samples were weighted by manual fish scale (accuracy $\pm 0,1 \mathrm{~kg}$ ) and kept in plastic bags for the analyses.

\subsection{Waste Characterization}

In the separation site, all samples were hand sorted into 11 primary waste categories and weighted. In order to assess the recycling potential of the wastes, each category was further subdivided into subcategories. Waste characterization of categories and subcategories were adapted from various waste characterization methodologies, mainly from SNI 19-3964-1994 standards. Waste categories included paper and paper products, plastics, organic (compostable) materials, glass, metals, textiles, construction and demolition wastes, wood, hazardous wastes, electronic wastes and others. The percentage for each category was calculated using the following equation:

$$
\mathrm{PC}=\left(\frac{\mathrm{PL}}{\mathrm{PT}}\right) \times 100
$$

where PC is the percentage of each category, PL is the amount of category present in $\mathrm{kg}$, and PT is the total weight of the sample in $\mathrm{kg}$.

\subsection{Determining the ZWI}

The waste diversion rate does not indicate the virgin material replacement efficiency of the waste management 
system, which is very important in conservation of global natural resources. Thus, the zero waste index is a cuttingedge tool to measure virgin material substitution bywaste management systems. By introducing the zero waste index globally, we could measure the virgin material offset potentiality and the potential depletion of natural resources. The ZWI is also a useful tool to compare different waste management systems in different cities and it gives a broader picture of the potential demand for virgin materials, energy, carbon pollution and water in a city. The ZWI is thus a performance indicator to assess the overall performance of waste management systems [5].

$$
\mathrm{ZWI}=\frac{\sum_{1}^{\mathrm{n}} \mathrm{WMSi} * \mathrm{SFi}}{\sum_{1}^{\mathrm{n}} \mathrm{GWS}}
$$

WMSi = amount of waste managed by system $\mathrm{i}$ (i.e. $\mathrm{i}=1$, $2,3 \ldots \mathrm{n}=$ amount of waste avoided, recycled, treated, etc.)

$\mathrm{SFi}=$ Substitution factor for different waste management systems based on their virgin material replacement efficiency
GWS = Total amount of waste generated (tonnes of all waste streams).

The $\mathrm{Z}$ is based on the value of material that can potentially replace the virgin material inputs. The substitution of energy, water and greenhouse gas emissions is also considered with the material substitutions. Substitution values for material, energy, water and greenhouse gases (GHG) emissions have been extracted from the life cycle database of different life cycle assessment tools and database sources. The amount of materials and resources substituted is positively related to the advancement of technology used in the material recovery process; therefore, the substitution value varies for different materials and for different waste management systems. Even though,waste prevention is one of the core components in the zero waste concept, but quantitative measurement of waste prevention by behaviour change has not been considered in this research due to limited scientific quantitative measurement data. Table 1 shows the substitution values for waste streams for different waste management systems.

Table 1. Substitution values of the resource from waste management systems for the Zero Waste Index

\begin{tabular}{|l|l|c|c|c|c|}
\hline $\begin{array}{c}\text { Waste } \\
\text { management } \\
\text { systems }\end{array}$ & \multicolumn{1}{|c|}{$\begin{array}{c}\text { Waste } \\
\text { category }\end{array}$} & $\begin{array}{c}\text { Virgin material } \\
\text { substitutions } \\
\text { efficiency } \\
\text { (tonnes) }\end{array}$ & $\begin{array}{c}\text { Energy } \\
\text { substitutions } \\
\text { efficiency } \\
\text { (GJLHV/tonne) }\end{array}$ & $\begin{array}{c}\text { GHG } \\
\text { emissions } \\
\text { reduction } \\
\text { (Tonne/CO } 2 \mathrm{e} \text { ) }\end{array}$ & $\begin{array}{c}\text { Water } \\
\text { saving } \\
\text { (kL/tonne) }\end{array}$ \\
\hline \multirow{4}{*}{ Recycling } & Paper & $0,84-1,00$ & $6,33-10,76$ & $0,60-3,20$ & 2,91 \\
\cline { 2 - 6 } & Glass & $0,90-1,00$ & $6,07-6,85$ & $0,18-0,62$ & 2,3 \\
\cline { 2 - 6 } & Metal & $0,79-0,96$ & $36,09-191,42$ & $1,40-17,8$ & $5,97-81,77$ \\
\cline { 2 - 6 } & Plastic & $0,90-0,97$ & $38,81-64,08$ & $0,95-1,88$ & $-11,37$ \\
\cline { 2 - 6 } & Mixed & $0,25-0,45$ & $5,00-15,0$ & 1,15 & $2,0-10$ \\
\hline Composting & Organic & $0,60-0,65$ & $0,18-0,47$ & $0,25-0,75$ & 0,44 \\
\hline Landfill & Mixed MW & 0 & $0,00-0,84$ & $(-) 0,42-1,2$ & 0 \\
\hline
\end{tabular}

References; [5]

\section{Results and Discussion}

\subsection{Solid Waste Generation and Composiion in FCEP UII}

Universitas Islam Indonesia (UII) was founded on 8th of July 1945, one month before the proclamation of Indonesian independence. Located in the northern outskirt of Yogyakarta. In 2016, UII has 24,202 students and 692 faculty members, distributed in 8 faculties (Faculty of Civil Engineering \& Planning, Economics, Law, Mathematics \& Natural Sciences, Psychology \& SocioCultural Sciences, Islamic Studies, Industrial Technology and Faculty of Medicine). The Faculty of Civil Engineering and Planning (FCEP) was founded in 12th of October 1964. It has 3 undergraduate programs (Environmental Engineering, Civil Engineering and Architecture), 1 master program of civil engineering and 1 architect professional program with 2841 students and faculty member are 112 .
Based on sampling shown that the average weight of solid waste generation in FCEP UII was $64,55 \mathrm{~kg}$ per day. Applying Equation (1) resulted the average composition of solid waste in FCEP UII Campus is organic $(28,38 \%)$, paper $(5,70 \%)$, plastic $(4,62 \%)$, and mixed $(61,28 \%$, mostly construction and demolition waste). Fig. 1 shows the composition of solid waste generation in FCSP UII Campus. Conducting a waste composition study is the first step if an effective waste management program development of campus are to be attained. It is estimated that the FCEP Campuss generate approximately $64,55 \mathrm{~kg}$ of waste per day, of which more than $35 \%$ may possibly be dealt with through waste reduction, recycling and composting activities. Compostable organic material was the most significant waste type. Therefore some strategies should be taken to manage these organic wastes. In addition, to manage other components of generated wastes in the FCEP UII Campus, there should be some plans to reuse and/or recycle them, included: reducing waste generation, reuse of generated wastes, composting 
of organic wastes, recycling of recyclable wastes, and disposal (landfill) of non-recyclable wastes.

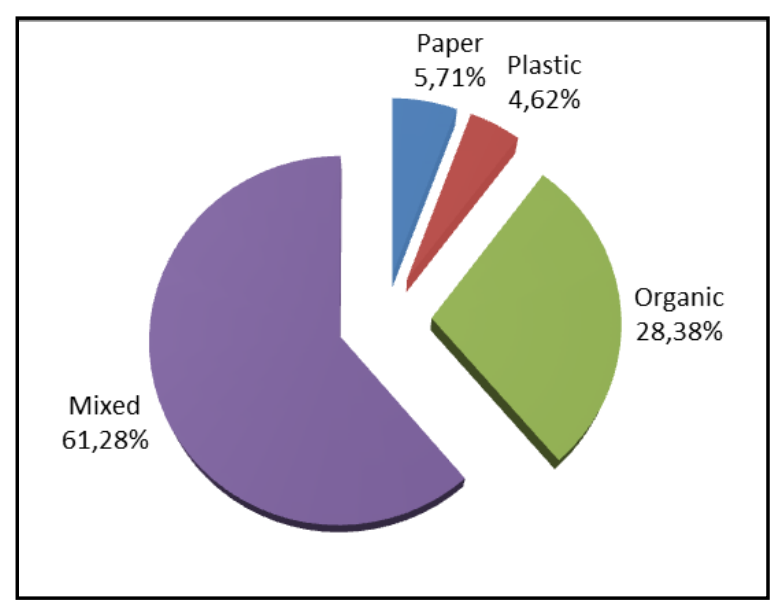

Fig. 1. Solid waste composition in FCEP UII Campus

\subsection{The ZWI in FCEP UII}

Base on Equation (2) and Table 2, the zero waste index in FCEP UII Campus is 0,26. That means around $26 \%$ of solid waste generation were recovered from the waste management systems. [4] study shows that in 2010 San Francisco achieved a $72 \%$ waste diversion rate with a ZWI of 0.51 . FCEP UII generated around $516,37 \mathrm{~kg}$ of waste every week and the resources recovered and potentially substituted for virgin material was $134,19 \mathrm{~kg}$. Waste management systems in FCEP UII potentially substitute the energy demand of 1139,64 megajoules (MJ). GHG emissions substituted were $-55,90 \mathrm{~kg} \mathrm{CO} 2 \mathrm{e}$ and total water savings from the waste management systems was -121,16 L per week.

The zero waste program in FCEP has not succeeded in reducing GHG emissions by producing $55.9 \mathrm{~kg} \mathrm{CO}_{2}$ per week. Where garbage was disposed to landfill which accounts for the largest $\mathrm{GHC}$ that is $132,91 \mathrm{~kg}$ of $\mathrm{CO}_{2}$, but for waste paper, plastics, and organic managed to reduce GHG, although not too large. Shown that paper, plastic and oranic waste can reduce of GHG amounted to 17.69 $\mathrm{kg}, \quad 22.68 \mathrm{~kg}, \quad 36.64 \mathrm{~kg} \mathrm{CO} 2$ of $\mathrm{GHG}$ per week respectively. Based on water saving, the zero waste program in FCEP UII also still not been successful because it become concume of water up to $121.16 \mathrm{~L}$. Plastic waste became the largest contributor in the water that is equal to $271.5 \mathrm{~L}$. The value is great because of the use of plastic bottles and plastic cups are relatively many in FCEP UII. But it helps in saving paper waste water, which can save $85.82 \mathrm{~L}$ and organic waste at $64.48 \mathrm{~L}$

Table 2. Potential substitution of resources in the zero waste index

\begin{tabular}{|l|l|r|r|r|r|r|r|}
\hline $\begin{array}{c}\text { Waste } \\
\text { management } \\
\text { systems }\end{array}$ & $\begin{array}{c}\text { Waste } \\
\text { category }\end{array}$ & $\begin{array}{c}\text { Total waste } \\
\text { managed } \\
\text { in the } \\
\text { campus }(\mathrm{kg})\end{array}$ & $\begin{array}{c}\text { Potential total } \\
\text { virgin material } \\
\text { substituted (kg) }\end{array}$ & $\begin{array}{c}\text { Total } \\
\text { energy } \\
\text { substituted } \\
(\mathrm{MJ})\end{array}$ & $\begin{array}{c}\text { Total GHG } \\
\text { emissions } \\
\text { reduction } \\
\left(\mathrm{kg} / \mathrm{CO}_{2 \mathrm{e}}\right)\end{array}$ & $\begin{array}{c}\text { Total } \\
\text { water } \\
\text { saving } \\
(\mathrm{L})\end{array}$ & $\begin{array}{c}\text { Zero } \\
\text { Waste } \\
\text { Index }\end{array}$ \\
\hline \multirow{2}{*}{ Recycling } & Paper & 29,49 & 24,77 & 186,67 & 17,69 & 85,82 & 0,26 \\
\cline { 2 - 7 } & Plastic & 23,88 & 21,49 & 926,59 & 22,68 & $-271,5$ \\
\hline Composting & Organic & 146,55 & 87,93 & 26,38 & 36,64 & 64,482 \\
\hline Landfill & Mixed & 316,46 & 0 & 0 & $-132,91$ & 0 \\
\hline Total & 516,375 & 134,19 & 1139,64 & $-55,9$ & $-121,16$ & \\
\hline
\end{tabular}

\subsection{Participation of Faculty Member and Student}

The zero waste program in FCEP UII involves all elements in the campus consists of faculty leaders, lecturers, academic staff and students. FCEP UII has committed to resource conservation, sustainability and environmental management and will take the initiative to apply material management methods and progressive zero waste practices. The form of activities through the reduction of consumption, the use of better materials, resource conservation and resource recovery on waste generated.

Faculty leaders have established policies on the implemntation of zero waste program in FCEP. Lecturers act as supervisors and educate all the elements in the campus to participate in the success of the zero waste program. While academic staff acts as a companion and field implementers such as placement and taking up to each container location. The student element that is the largest number of campus residents is to be very strategic for participation. Zero waste program in FCEP has established a task force of students with a total of 30 people, it aims to monitor and invite directly to all students to participate in handling waste in the campus environment.

The socialization activities are routinely conducted by the zero waste team to all FCEP elements. It intended to know the response and invite all campus residents to zero waste program. The form of socialization is done through posters, social media, and quesionnair. Based on the questionnaire, it is known that some campus residents have not understood about zero waste program in FCEP that is $29 \%$, while $99 \%$ of campus support and agree with the program.

\section{Conclusions}

The study is a time series measurement of waste management performance in FCEP UII based on the ZeroWaste Index tool. From the assessment analysis, the study concludes that despite a potentially higher diversion rate $(134,19 \mathrm{~kg}$ from $516,37 \mathrm{~kg}$ of waste generated) in 2016. FCEP UII may not be significantly advanced in virgin materials substitution and resource recovery by then and the projected ZWI would be 0.26 . Participation of all faculty members and student in FCEP on zero waste 
program are very good, although the understanding of zero waste program still needs to be improved, because only $29 \%$ already understand.

This study is part of an on-going research project studying strategies for zero waste material flows conducted at the Zero Waste Program at the UII. The authors would like to give a special thanks to Mr. Dr Ing. Widodo Brontowiyono, dean of FCEP UII that has supported the study of the evaluation of zero waste programs in FCEP.

\section{References}

1. Wilson, D., Velis, Costas, Cheeseman, Chris, 2006. Role of informal sector recycling in waste management in developing countries. Habitat Int. 30, 797-808.

2. Damanhuri, E., Handoko, W., Padmi, T., 2010. Municipal Solid Waste Management in Indonesia, Faculty of Civil and Environemntal Engineering, ITB, Bandung-Indonesia

3. Zhang, N., Williams, I.D., Kemp, S., Smith, N.F., 2011. Greening academia: Developing sustainable waste management at Higher Education Institutions, Journal of Waste Management 31 (2011) 1606-1616.

4. Zaman, A.U., Lehmann, S., 2013. The zero waste index: a performance measurement tool for waste management systems in a 'zero waste city', Journal of Cleaner Production, 50 (2013) 123-132.

5. Zaman, A.U., 2014. Measuring waste management performance using the 'Zero Waste Index': the case of Adelaide, Australia, Journal of Cleaner Production 66 (2014) 407-419.
6. Taghizadeh, S., Ghassemzadeh, H.R, Vahed, M.M., Fellegari, R., 2012. Solid waste characterization and management within university campuses case study: university of Tabriz, Elixir Pollution 43 (2012) 66506654.

7. Kinuthia, J.M., Nidzam, R.M., 2011. Towards Zero Industrial Waste: Utilisation of Brick Dust Waste in Sustainable Construction. Waste Management 31 (2011), 1867-1878.

8. Phillips, P.S., Tudor, T., Bird, H, Bates, M., 2011. A Critical Review of a key Waste Strategy Initiative in England: Zero Waste Places Projects, Resources, Conservation and Recycling, 55, (2011), 335-343.

9. Zaman, A.U, Lehmann, S., 2011. Urban Growth and Waste Management Optimization Towards 'Zero Waste City'. City Cult. Soc, 2 (2011), 177-187.

10. Curran, T.,Williams, I.D., 2012. A zero Waste Vision for Industrial Networks in Europe, Journal of Hazardous Materials, 208 (2012), 3-7.

11. Yoshida, H., Gable, J.J., Park, J.K., 2012. Evaluation of organic waste diversion alternatives for greenhouse gas reduction. Resour. Conserv. Recycl. 60, $1-9$.

12. Mazzanti, Massimiliano, Montini, Anna, Nicolli, Francesco, 2009. The dynamics of Landfill Diversion: Economic Drivers, Policy Factors and Spatial Issues: Evidence from Italy Using Provincial Panel Data, Resources Conservation and Recycling 54 (2009), 53-61.

13. Mueller, W., 2013. The effectiveness of Recycling Policy Options: Waste Diversion or Just Diversions, Waste Managemrnt, 33 (2013), 508-518. 